\title{
The Development of Passenger Intermodality Transport and Its Demand Analysis
}

\author{
Ying Liu \\ Academy of Transportation Sciences \\ Beijing, CN 100029 \\ ice_liuying@163.com \\ Xiao-nian Sun \\ Academy of Transportation Sciences \\ Beijing, CN 100029 \\ sunxiaonian@126.com \\ Qingfeng Kong \\ Academy of Transportation Sciences \\ Beijing, CN 100029 \\ kqf29@163.com
}

\author{
Ming-jun Liao \\ Dept. of Civil Engrg, Beihua Univ. \\ Jilin, Jinlin Prov., CN 132013 \\ mingjunliao@gmail.com \\ Jian Wang \\ Academy of Transportation Sciences \\ Beijing, CN 100029 \\ Wangjian115@gmail.com \\ Tiejun $\mathrm{Hu}$ \\ Academy of Transportation Sciences \\ Beijing, CN 100029 \\ Bvbv_htj@yeah.yet
}

\section{THE STATE-OF-THE-ART OF PASSENGER INTERMODALITY}

\begin{abstract}
Comprehensive transportation is the key point of all countries. Passenger and cargo transport pay attention on seamless connection and transfer. The paper discussed the state-of-the-art at home and abroad, and the state-of-the-art of the railway-highway intermodality, train-and-bus intermodality, air-railway intermodality, and highwayshipping intermodality of domestic airlines. The paper also discussed the abroad intermodality situation from operating level and research level. Through comparative study, problems were found in the field of intermodality, then intermodality demand is analyzed, at last, the orientation of the future passenger intermodality .
\end{abstract}

Keywords- passenger; intermodality; transport; demand; analysis;

\section{INTRODUCTION}

Integrated transport is focused in the world at present, intermodal transportation reflects the mission and quality of transportation system. The last decade, it has become the focus of the European and national transport policy concerned. Foreign countries have attempted to carry out air-rail passenger transport services, Germany, Britain and Japan had a positive attempt, and achieved remarkable results. With the improvement of transport infrastructure networks, domestic passenger intermodality demand growing up more and more with time goes by, but less in research of transport compared with foreign countries. In order to promote effective convergence of various modes of transport and zero distance transfer and to improve service level of integrated transport system, it must be clear of trends and directions of passenger intermodality transport.

\section{A. Railway-highway intermodality}

Railway-highway intermodality in China can date back to 19760s and 1970s. In Jan, 1960, Futian County founded transport headquarters for railway-highway intermodality , and start the railway-highway intermodality service for the first time. On May 1, 1960, a coordinated process passenger transport squad is founded, and start the service of passenger intermodality , integrated the eight train transit stations of Fuzhou, Xiamen, Nanping, Yongan, Zhangping, Shaowu, eyang, and Sanming, and the 33 main inter-city bus stations as a Consortium starting the streamlined services of ticketing, accommodation, travel for passengers. Till September, 10629 person trips of highway-railway intermodality and 2102 cosigned luggage were finished[1].

In recent years, highway-railway intermodality was rare in China. In some cities, highway-railway intermodality service is carried on during special time like spring festival.

\section{B. Air-railway intermodality}

Home airline companies, for example, China Eastern Airlines, China Hainan Airlines, Hebei airlines, and Chunqiu airlines, are carrying on air-railway intermodality .

1)The air-railway intermodality status of China Eastern Airlines

On May, 5, 2012, China Eastern Airlines and railways bureau referring to the experiences of Deutsche Lufthansa, together launch the first air-railway intermodality service named "kong tie tong", which realize the two-way cohesion intermodality services of Suzhou, Wuxi, 
Changzhou, Ningbo, together with China Eastern Airlines in Hongqiao and Pudong airport. Until the end of 2013, 59.8 thousand person trips with 4982.5 person trips per month are transported.

TABLE I. THE KONGTIETONG OPERATING SITUATION OF CHINA EASTERN AIRLINES IN 2013(TWO-WAY)

\begin{tabular}{|c|c|c|}
\hline Cities & Daily average shifts & Passenger number \\
\hline HANGZHOU & 27 & 14417 \\
\hline NANJING & 24 & 12235 \\
\hline TAIZHOU & 12 & 9298 \\
\hline SUZHOU & 24 & 8452 \\
\hline WUXI & 26 & 4643 \\
\hline NINGBO & 12 & 2454 \\
\hline CHANGZHOU & 19 & 1975 \\
\hline JIAXING & 25 & 1523 \\
\hline TONGXIANG & 15 & 1427 \\
\hline KUNSHAN & 20 & 1372 \\
\hline YIWU & 12 & 885 \\
\hline DANYANG & 15 & 737 \\
\hline ZHENJIANG & 19 & 372 \\
\hline The total & 250 & 59790 \\
\hline
\end{tabular}

2)The air-railway intermodality status of China Hainan Airlines

On Feb., 23, 2012, Hainan airlines, Yuehai railway Co., Ltd, and Hainan Meilan international airport jointly issued the service named "air-railway transport straightly", declare that the service went online. Passengers can buy the air tickets of all airlines in the airport plus Hainan east ring high speed railway tickets nationwide. The air tickets include a virtual air ticket, that is, the train ticket from Meilan to Sanya.

3)The air-railway intermodality status of China Hebei Airlines

In 2013, Hebei airlines together with Shijiazhuang airport created the system of air-railway express. Passengers can fly to Shijiazhuang airport from 60 cities nationwide, then take free airport shuttle bus to Zhengding high-speed rail station, then show air ticket and ID card ,and get the ticket at specified ticket window, at last, take train to periphery cities around Shijiazhuang.

4)The air-railway intermodality status of Chunqiu Airlines

In Aug., 2013, Spring Airlines declare built an hour's low cost air-railway express circle, start the service of airrailway intermodality in Suzhou, hangzhou, jiaxing, wuxi, Changzhou.

5)The air-railway intermodality status of Hong Kong new airport

HK international airport was opened on Jul., 6, 1998, and adopted airport special express train to transport passengers to airport from city center by the $35 \mathrm{~km}$ exclusive rail line. Exclusive rail line begins from Hong Kong central station, pass Jiulong station, Qingyi station, and arrives at airport. Passengers of all airlines can check in, free check or claim baggage at HK station and Jiu long station. The intermodality systems of two stations is each composed of 28 computers and 33 computers. The service can be finished in 90 minutes before flying. After large luggage checking, luggage is inspected by $\mathrm{X}$-ray, then sorted according to the types of flights on express train, sealed in containers, in the end, transports to airport by inclusive luggage vans. HK airport express expressed that $53 \%$ of airport express passengers chose urban terminal to check in and check luggage, and the percentage reached $70 \%$ during peak hour.

The railway-air intermodality provided by HK new international airport is the joint of rail transport and air transport in essence. Passengers do security check and clear in the off sites without paying additional fee for luggage checking during the Middle process.

\section{TABLE II. AIR-RAILWAY INTERMODALITY STATUS OF HK NEW} INTERNATIONAL AIRPORT

\begin{tabular}{|c|c|c|c|c|}
\hline $\begin{array}{c}\text { Passenger } \\
\text { check-in }\end{array}$ & $\begin{array}{l}\text { Luggage } \\
\text { Checking }\end{array}$ & $\begin{array}{c}\text { Baggage } \\
\text { carrier }\end{array}$ & $\begin{array}{c}\text { Ticketing } \\
\text { system }\end{array}$ & $\begin{array}{l}\text { Service } \\
\text { objects }\end{array}$ \\
\hline $\begin{array}{l}\text { Provide } \\
\text { service of } \\
\text { Check-in at } \\
\text { Hong Kong } \\
\text { station and } \\
\text { Jiulong } \\
\text { station of } \\
\text { airprt } \\
\text { express } \\
\text { lines }\end{array}$ & $\begin{array}{l}\text { Provide } \\
\text { Luggage } \\
\text { Checking but } \\
\text { should } \\
\text { experience } \\
\text { security } \\
\text { check at } \\
\text { airport again }\end{array}$ & $\begin{array}{l}\text { Rail } \\
\text { vehicles }\end{array}$ & $\begin{array}{l}\text { No } \\
\text { available } \\
\text { joint ticket }\end{array}$ & $\begin{array}{l}\text { Passengers to } \\
\text { Gangzhou } \\
\text { and } \\
\text { Shenzhen } \\
\text { airports }\end{array}$ \\
\hline
\end{tabular}

\section{Highway-air intermodality}

1)the highway-air intermodality current situation of Eastern airlines

On Aug., 15, 2013, China Eastern airlines announced the services of highway-air intermodality named as "Kongbatong" which is the extension of "Kongtietong". Chian Eastern airlines integrated air services with longdistance bus services, and sold the virtual air ticket include bus ticked. From Aug. to Dec. China Eastern airlines succeeded in transport 2015 Kongbatong passengers, that is, 403 passengers per month. Shanghai-Suzhou, ShanghaiKunshan, and Shanghai-Wuxi lines is the most steady lines among the intermodality lines.

2)Overview on the state-of-the-art of air-land intermodality development

Air China in Dec., 2010 firstly start air-land in Beijing, later, on April. 15, 2011, launched "freely transport air and land" intermodality services in Shanghai, Chengdu, and Guangzhou. Air China is responsible for not only flight segment, but also land transport segments include Shanghai long-distance west station-Ningbo, Yiwu and Hangzhou, Guangzhou-Dongguan, Foshan, Zhongshan, and Zhuhai, and Chengdu-Deyang.

Before buying ticket, Air China has input virtual flight of bus segment into airport ticket system. The system will give passenger integrated ticket price, transport the information to bus station, so passenger can directly board bus without buying ticket again. On the contrary, passenger can buy bus ticket include air ticket and directly check in at airport with buying airport ticket again.

At present, "air-land" intermodality is limited to home airlines and there is no discount in long-distance ticket. If Air China launched combined marketing program, passengers is promised to take on free long-distance bus. 


\section{OVERVIEW ON THE STATE-OF-THE-ART OF INTERMODALITY DEVELOPMENT}

\section{A. Intermodality operating level}

Abroad countries have carried on the attempts of airrail intermodality service. In 1959, Brussels carried passengers check-in in cities. Belgium national railway provided railway transport, and also airport bus express service. At the same time, Germany, Britain, and Japan attempted to carry on the services of intermodality, and got significant effect. air-rail intermodality of Frankfurt Airport is a typical case. The main services of intermodality are passenger check-in, luggage transport, and ticket system[2]. Frankfurt Airport is an intermodality Airport in real sense. Passenger at Frankfurt Airport can realize "check in once, and pass through anywhere"

Due to high developed high-speed railway, and aviation in Europe, at the begin of last century, European airports carried on the services of air-rail intermodality with the support of improved railway network and obtained a certain success[3].

TABLE III. AIR-RAILWAY INTERMODALITY PROFILES OF FORGEIN INTERNATIONAL AIRPORT

\begin{tabular}{|c|l|l|}
\hline \multicolumn{1}{|c|}{ Airport } & Passenger check-in & \multicolumn{1}{c|}{ Luggage Checking } \\
\hline $\begin{array}{l}\text { Frankfort International } \\
\text { Airpor }\end{array}$ & $\begin{array}{l}\text { Provide service of } \\
\text { Check-in at Hong } \\
\text { Kong }\end{array}$ & $\begin{array}{l}\text { Provide Luggage } \\
\text { Checking in the Entire } \\
\text { journey }\end{array}$ \\
\hline $\begin{array}{l}\text { London Heathrow } \\
\text { International Airpor }\end{array}$ & $\begin{array}{l}\text { Provide service of } \\
\text { Paddington Station } \\
\text { of airprt express } \\
\text { lines }\end{array}$ & $\begin{array}{l}\text { Provide Lecking but should } \\
\text { experience security } \\
\text { check at airport again }\end{array}$ \\
\hline Baggage carrier & \multicolumn{1}{|c|}{ Ticketing system } & \multicolumn{1}{c|}{ Service objects } \\
\hline Rail vehicles & available joint ticket & $\begin{array}{l}\text { Only for passengers of } \\
\text { Deutsche Lufthansa }\end{array}$ \\
\hline Freight car & $\begin{array}{l}\text { No available joint } \\
\text { ticket }\end{array}$ & $\begin{array}{l}\text { Passengers to London } \\
\text { Heathrow } \\
\text { International Airport }\end{array}$ \\
\hline
\end{tabular}

\section{B. Intermodality research level}

Project titled as "Towards Passenger Intermodality in the EU" funded by DG TREN studied the current situation, key problem, and its barriers of implementing intermodality, and gave its advice and policies[4].

From development policy, from 1990, EU drafted the Green books of COM (92)46(Green Paper on the impact of transport on the environment) and the Green Paper on the Citizen's network and presented service policies.it is required that intermodality should be included in traffic planning process. In 1995, The Task Force on Transport Intermodality (1995-1997) is formed to promote the progress on technology, system, innovation and policy, and enhance the tactics of cargo and passenger intermodality services. In 2011, EU issued a white book named as "Roadmap to a Single European Transport Area - Towards a competitive and resource efficient transport system" in which EU presented three key points: integrated ticketing, luggage transport, and trip continuity[5].

For the technical problems of passenger intermodality, from the end of 19 centuries, EU in the 4th and 5th Framework Programme implement the study program about intermodality technology. Especially in electric ticket and information system, EU carried on many researches, case studies in IST and TAP-T programme, furthermore, integrates the transportation information projects with the support of IST CODE and ROSETTA. ATLANTIC project further studies intermodality and trip information system and attempted to build the EU-wide Intermodality system[6][7].

\section{EXISTING PROBLEMS}

Based on above overview, we found some problems in current situation and standards:

1)china can not realize an all-inclusive ticket for the time being due to the incompatible interfaces of the ticket system of aviation, railway, and highway. Passengers abroad can buy tickets and balance accounts across multimode with an all-inclusive ticket[8].

However, in China, each department has its dependent ticketing system, and is not compatible with each other. In order to realize the passenger intermodality ticketing system unifying the modes of railway, civil aviation, highway, and water.

2)In passenger intermodality , there are problems in luggage transportation and multi-mode check in

Abroad passenger intermodality have realized an allinclusive ticket. Luggage transport and passenger trip is still independent, cannot implement luggage transport in other destinations between Airlines railway, and highway modes in China.

In order to the attractiveness of passenger in other destinations using intermodality, luggage delivery is important. Realizing the function of luggage delivery in other destinations means the separation of passenger and its luggage, or the separation of passenger trip chain and luggage trip chain, so it brings great convenience for passengers, however, it means challenge for the service of intermodality .

3)The key problem of promoting passenger intermodality standards

Setting passenger intermodality standards is the key for promoting intermodality .

Forever countries have set relevant standards to promote and regulate the development of intermodality , however in China each department manage its business and system. There are many barriers in infrastructure, operating network, marketing entry and service standard. Which curb the development of passenger intermodality . It is urgent that unified intermodality ticket standard (ticket form, electronic ticket), luggage checking (luggage ticket form, service regulations), and intermodality services (service regulations) should be unified.

\section{PASSENGER INTERMODALITY DEMAND ANALYSIS}

From the existing problems in passenger intermodality , the demand of future passenger intermodality development is listed as: 


\section{1)ticket business of Passenger intermodality}

From passenger intermodality of developed countries (for example, air-railway intermodality at Frankfurt airport in Germany), passengers can make a trip by an allinclusive ticket to finish a multimode trip[9]. The airrailway and air-land intermodality $\mathrm{s}$ in China show the embryo of passenger intermodality of developed countries, however, passengers still go to station to get ticket. The barriers lie in the dependent ticketing system, the difference of electric ticket and OD encoding (for example, IATA standard for airlines, special standard for railway), the lack of exchange and share of passenger, trip and ticket information. At the same time, due to the independence of ticket system in China, the settlement and allocation of intermodality ticket fare is in half automatic mode, for example, Eastern airlines manually finishes the settlement of intermodality ticket fare based on the ticket information .

At present all airlines are carrying on multi-mode passenger intermodality services. From the "air-railway intermodality ", and "air-bus intermodality " of China Eastern airlines, the intermodality services are recognized and accepted by the public.

Passenger intermodality is the important point of promoting comprehensive transportation service. In order to provide an all-inclusive ticket service for passengers, it needs to build the service platform of Passenger intermodality to realize the purchase of through ticket, and settlement and allocation of ticket fare.

2)multi-mode luggage through transport services

At present, luggage shipping of multi-mode passenger intermodality abroad is finished by one single consignment[10]. The shipper is responsible for the automatic transfer of luggage from multi modes. The case is the planning without transferring their luggage in Japan. The luggage is automatically transferred and transported by the FRID on the luggage.

In China, the luggage do not implement the automatic transfer in air-railway, and air-road intermodality. There are many issues on the service support and implementation technology on security check, insurance, compensation and operation pattern, in addition, luggage automatic sorting based on RFID, QR Code.

From the aspect of enhancing comprehension transportation service, One-stop transport of luggage in intermodality is the key for the practice of comprehensive transportation services. The solution of service support technology and implementing technology can effectively implement the services of multi-mode through transport.

3)the standardized orientation of passenger intermodality

Each transport mode has its mature standard and Regulations in passenger ticket business, through ticket, electronic ticket, and trip information, therefore, in orders to carry on multi-mode intermodality , the issue on the unified standards of intermodality services must be solved during operation. Because there are no unified intermodality ticket standard (ticket form, electronic ticket), luggage checking (luggage ticket form, service regulations), and intermodality services (service regulations), the current market of intermodality is lack of unified guidance. How to combine advanced international standards with the state of the art and future direction of intermodality in China and providing the passenger intermodality standard is the key for localizing international standard and guiding the development of intermodality in China.

\section{CONCLUSIONS}

With the development of comprehensive transportation system, some urgent problems is exposed. For passenger intermodality, at present, unified standard and technology requirement are lacked. There are no unified interface and information exchange standard; and there are no reliable evaluation criterion of intermodality services. All those restrict the development of intermodality in China.

Standards go before industry development. Building the standard system of passenger intermodality , standardize operation and management of passenger intermodality, and guiding the development of passenger intermodality, are the tools for urge the comprehensive transportation system

\section{ACKNOWLEDGMENT}

The authors would like to thank the support of Academy of Transportation Sciences fund, National Natural Science Foundation of China(51108289), National Social Science Fund(13\&ZD175), Natural Science Foundation of Jiangsu provincial universities(10KJB580003).

\section{REFERENCES}

[1] Yu Min. Study on Processing of Baggage in Air \& Rail Intermodality in Yangtze Delta[D]. Shanghai: Tongji University, 2008.

[2] Huang Xuan. Feasibility Study on Passenger Transportation of Air \& Rail Integration[D]. Shanghai:Tongji University, 2008.

[3] Qin Can-can. Xu Xun-chu. Frankfurt Airport's Air and Railway Transport[J]. Traffic and Transport (Academic Version), 2005, Vol2: 46-48.

[4] Funded by the European Commission's Directorate-General for Mobility and Transport DG MOVE Towards Passenger. Towards Passenger Intermodality in the EU[R]. European Commission, 2004.

[5] Wu Nian-zu. Resarch on Passenger Intermodality in Hongqiao Integrated Transport Hub[M]. Shanghai: Shanghai Science and Technology Press. 2010

[6] Qin Can-can. Zhao Ya-li. Wang Ming-yan. Study on Air \& Rail Intermodal Baggage Service in Yangtze Delta[J]. Shanghai Airport, 2009. Vol9:112-114

[7] Yang Qin. Research on the Legal Issues of International Passenger Transport by Railway-Taking ComParative Research on Regulations as Perspective[D]. Beijing: Beijing Jiaotong University,2011.

[8] Zhang Hong-yu. Shi Tian-yun. The Development Status of CyberRail in Intermodal Transport System of Japan[J]. Journal of Transportation Systems Engineering and Information, 2004. Vol4. No.2: 25-30.

[9] Shang Feng. The implementation of Air-ground transportation intermodality. Guangzhou: Zhongshan University, 2013.

[10] Song Xiang-bo. Liu Guan-ying. Study on the Development of Civil Aviation and High-speed Railway Based on Air-Rail Integration Model. Journal of Civil Aviation Flight University of China, 2012. Vol23. No.2: 5-9. 